\title{
The Effects of Training and Reward Systems on Employee Willingness to Stay - A Case Study of an International Tourist Hotel in Taipei
}

\author{
${ }^{1}$ Ya-Hsin Cheng, ${ }^{2}$ Hung-Sheng Herman Lai \\ ${ }^{1}$ Department of Leisure and Recreation Management, Chihlee University of Technology, Sec. 1, \\ Wunhua Rd., Banciao Dist., New Taipei City, Taiwan (R.O.C.) \\ ${ }^{2}$ Department of Restaurant, Hotel and Institutional Management, Fu Jen Catholic University, \\ Zhongzheng Rd., Xinzhuang Dist., New Taipei City, Taiwan (R.O.C.)
}

\begin{abstract}
The hotel industry is an extremely labor-intensive service industry that sees volatile demand and distinct high and low seasons. Human resources are the foremost assets of a hotel and can be regarded as a condition of market competition. Human resource management covers a wide range of issues. The majority of existing studies on the human resources of hotels have focused on training development, compensation and benefits, and the turnover intentions of employees; in contrast, there is little research on the influence of reward systems on willingness to stay has, particularly as it pertains to international tourist hotels. In view of this, we used questionnaires to examine the relationship between employee willingness to stay, and training and reward systems in an international tourist hotel.

The constructs we examined were training system, reward system, and employee willingness to stay. The demographics of employees were also taken into consideration. The subjects of this study were the employees of an international tourist hotel in Taipei. We distributed 427 questionnaires and recovered 352 questionnaires. After eliminating the incomplete questionnaires, we obtained 342 valid questionnaires, thereby contributing to a valid sample ratio of $82.9 \%$.

The results revealed a positive correlation between satisfaction with the training system and willingness to stay. A positive correlation also existed between the reward system and willingness to stay, and employee views regarding the effectiveness of the training system varied significantly with various demographic variables.
\end{abstract}

Keywords: international tourist hotel, training system, reward system, willingness to stay

\section{INTRODUCTION}

\subsection{Research Background and Motives}

The hotel industry is one of the most labor-intensive service industries. Hotel services are inseparable and perishable, and hotels have distinct high and low seasons. As a result, they need unique arrangements for employee scheduling and business hours (Huang, 2006). Statistics compiled by the Tourism Bureau of Taiwan in November, 2016, indicate that there are 75 international tourist hotels in Taiwan. Among these hotels, 36\% (or 27 hotels), are situated in Taipei City (Taiwan Tourism Bureau, 2016).

Chen (2005) stated that human resources are the foremost resources of a hotel and can be regarded as a condition of market competition. Hotels attach a great deal of importance to how they make use of their employees, and it's vital that they value their employees. Enhancing the quality and abilities of management personnel is a major factor in corporate success (Wu, 2004). The purpose of training programs is to make up for the difference between the objectives of a business and the abilities demonstrated by internal human resources. Comprehensive training systems can cultivate needed talent and improve employee knowledge and skill. Employees can gain promotion opportunities through training, which motivates them to learn. At the same time, training facilitates the achievement of corporate objectives and promotes the philosophy espoused by the organization.

Incentive systems play a crucial role in human resource management (Saks, 2006). The incentive systems that corporations adopt to motivate their employees can be divided into two major categories: reward systems and punishment systems. Reward systems encourage employees that perform well and 
offer positive motivation, giving employees job satisfaction and pleasure while motivating unrewarded employees to perform better. In contrast, punishment systems penalize employees with poor work performance or deviant behavior and are a type of negative motivation. Such incentive systems can create some motivation but also tend to bring about displeasure or grievances (Chung, 2007). Material rewards also play a significant role in human resource management. Studies have noted that supervisors generally give higher performance appraisals to senior employees, as they assume that experience means better work performance. However, this assumption is not reasonable; junior employees can also display high performance via the pursuit of new skills and knowledge. Whether this is a factor of employee turnover and whether junior employees can accept performance appraisal results and stay with a company are also issues examined in this study.

We used an international tourist hotel (label as hotel $\mathbf{A}$ in this study) in Taipei as the study case. The business philosophy of hotel A focuses on providing guests with warm hospitality, being innovative and considerate, and considering their employees as family. The majority of the employees at the hotel A are veterans of the hotel industry. How can less experienced employees be retained so as to prevent talent gaps? Many international tourist hotels have been established in the last decade, and employee retention can be difficult. Might a comprehensive training system and reward system enhance employee quality and increase their willingness to stay? Retaining good talent is the key to improving operating efficiency and customer retention.

In light of the background and motives listed above, this study made a review of the literature associated with the training systems and reward systems in hotel human resource management and employee willingness to stay. It is hoped that the results of this study can provide hotels with reference for the planning of personnel systems.

\section{LITERATURE REVIEW AND RESEARCH FRAMEWORK}

\subsection{Training}

The purpose of training is to enhance the knowledge and skills of employees and improve their performance in a planned, organized, and systematic manner. Educational training is a learning experience and can bring positive benefits to an organization, enhance employee knowledge and skills, improve employee quality and attitude, and improve job performance (Robbins, 1978). Dessler (2005) outlined five steps in a comprehensive educational training program: 1. A needs analysis, which involves identifying deviance or inadequacies in performance, determining whether these can be rectified with training, and establishing a detailed and achievable target; 2 . Instructional design, which involves setting training objectives with measurable standards; 3. validation, which involves doing test runs with a small number of employees and eliminating unsuitable training methods; 4. implementation of the training program; 5. evaluation, which involves assessing and comparing the performances of employees before and after training to examine the effectiveness of the training. We therefore define training systems as a means of validating and evaluating the development of an individual via planned learning so that said individual can successfully execute their current and future tasks (Mclagan et al., 1983).

\subsection{Rewards}

Motivation theories form the theoretical basis of reward systems. Encouragement is the foundation of personnel management in an organization. Researchers commonly define punishment as the use of negative methods to correct inappropriate behavior (Trevino, 1992; Butterfield et al., 1996). This means applying reinforcement theory, which is a common approach to shape behavior. We therefore defined rewards as recompense for contributions made.

\subsection{Willingness to Stay}

Feng (2002) observed that employees that are older, have served longer, or are more enthusiastic are more committed to their organization and are less likely to generate the idea of quitting. In contrast, younger employees are more likely to experience work-related stress. In an organization with an uncomplicated work force, effective communication with employees reduces turnover intention. In order for employees to be willing to stay, corporations must establish appropriate pay and performance systems and people-oriented methods of reform. Managers must treat employees fairly, set up reward systems, and give employees challenges, the power to participate in decision making, and educational training as is appropriate. They must value and adequately respond to employee needs, give them suitable authority, and take note of their career development plans and personal willingness to contribute. These will promote good relationships between employees and managers, which will also reduce training costs and greatly increase the success of talent retention (Lin, 2007). 
This study investigated whether the responses and opinions of employees with regard to reward systems within vary with the age, educational background, and monthly income of the employee. Based on these motives, we formulated Hypotheses 1, 2, and 3.

H1: The employees of different demographics influence their responses to training systems.

H2: The employees of different demographics influence their responses to reward systems.

H3: The employees of different demographics influence their willingness to continue employment with an international tourist hotel.

\subsection{Training Systems and Willingness to Stay}

Schuler and Jackson (1987) discovered that an effective initial training reduces the time and costs needed for on-the-job training, enhances employee work confidence and satisfaction, gains employee commitment to the organization, strengthens employee cognition regarding the organization, decreases employee turnover and absence rates, and increases employee productivity and their willingness to stay. Lin (2007) established that the effectiveness of educational training is significantly correlated to the degree of organizational commitment; educational training, participation, work engagement, job satisfaction, benefits, and rewards have a positive impact on willingness to stay, and effective educational training and greater cognition promote commitment, willingness to stay in the organization, and productivity. Thus, we proposed Hypothesis 4:

H4: The effectiveness of the training system of an international tourist hotel is significantly correlated with the willingness of employees to stay.

\subsection{Reward Systems and Willingness to Stay}

Chang (2001) discovered that interviewees displayed concern regarding monetary compensation; those that received more financial rewards (such as year-end bonuses and bonuses given during three Chinese festivals) felt greater job satisfaction and lower turnover intention. Researchers in the past presented six types of reward systems. The most preferred was educational training, followed by work rotation and bonuses. The next most preferred was rewards, and the last were promotions and commendation. Their results indicated that if employees perceive higher overall degrees of fairness, controllability, expectation, and communication in the reward system, employees will feel greater job satisfaction and demonstrate lower turnover intention. Wang et al. (2005) discovered that support from family and superiors exerts a significant influence on job satisfaction as well as willingness to stay; married and older employees are more willing to stay, and promotion opportunities are also significantly correlated with willingness to stay. We therefore propose Hypothesis 5:

H5: The reward system used by an international tourist hotel is significantly correlated with the willingness of employees to stay.

To examine the connection between various employee demographic variables (such as gender, marital status, age, educational background, monthly income, department of employment, position, years of service, and child status) and the training system, reward system, and willingness to stay, we constructed the following framework based on our research objectives and relevant literature.

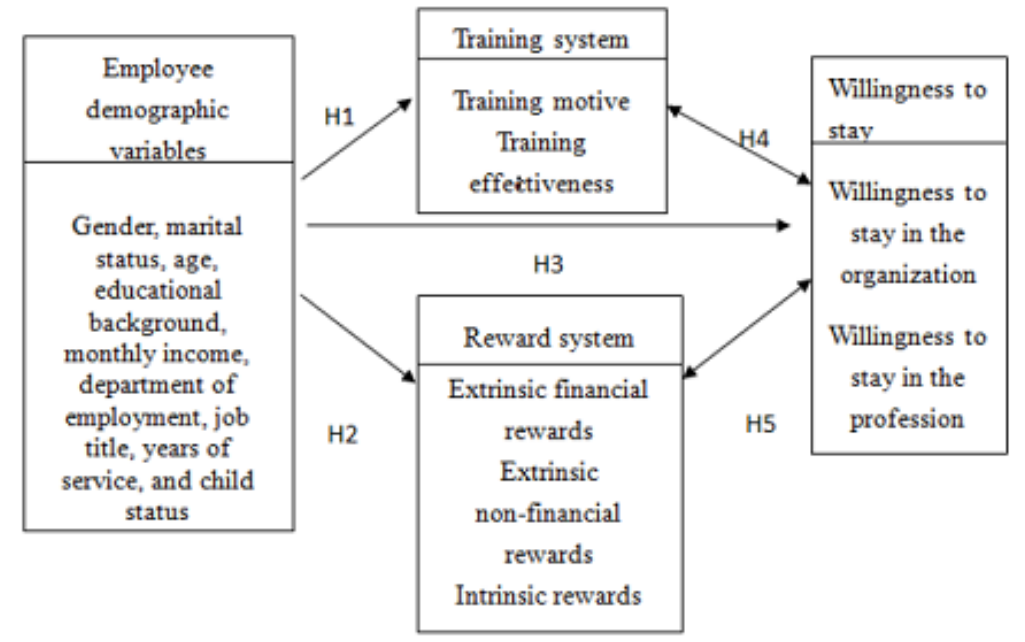

Fig1. Research Framework 


\section{Methodology}

\subsection{Research Subjects and Sampling Method}

We took a census with a questionnaire survey as our primary research instrument. First we conducted a pilot test questionnaire then proceeded with the official questionnaire. The question items of the pilot test questionnaire were checked for reliability, typos, and ambiguous wording and were recompiled into the official questionnaire following recovery and analysis. The subjects of this study were the 427 employees of the hotel A in Taipei.

\subsection{Questionnaire Design}

We adopted a five-point Likert scale for the questionnaire. The questionnaire covered personal information as well as constructs revised from past studies (Chang, 2007; Hu, 2005; Huang, 2003; Lee, 2003; Lin, 2007) regarding training systems, reward systems, and willingness to stay.

\subsection{Pilot Test Analysis}

The reliability of our research instrument was tested using Cronbach's $\alpha$ to confirm the behavioral consistency of recovered samples. The reliability of all the questionnaire items was 0.962 , and all Cronbach's $\alpha$ values were greater than 0.7 , thereby indicating that the questionnaire has good reliability. Thus, the pilot test questionnaire was adopted as the official questionnaire with no question items eliminated.

\section{RESUlts}

\subsection{Distribution of Sample Characteristics}

The subjects of this study were the employees of the hotel A in Taipei. The researcher personally asked management in each department to distribute the questionnaires. A total of 427 questionnaires were distributed, and 352 questionnaires were recovered. These included 10 invalid questionnaires, which resulted in a value questionnaire recovery rate of $82.9 \%$. Table 1 presents the statistics of various demographic variables.

Table1. Statistics of Respondents

\begin{tabular}{|c|c|c|c|}
\hline \multicolumn{2}{|c|}{ Variables } & Number of people & Percentage \\
\hline \multirow[t]{2}{*}{ Gender } & Male & 141 & 41.2 \\
\hline & Female & 201 & 58.8 \\
\hline \multirow[t]{2}{*}{ Marital status } & Single & 180 & 52.6 \\
\hline & Married & 162 & 47.4 \\
\hline \multirow[t]{4}{*}{ Age } & 18-30 years old & 130 & 38.0 \\
\hline & $31-40$ years old & 95 & 27.8 \\
\hline & $41-50$ years old & 63 & 18.4 \\
\hline & over 51 years old & 54 & 15.8 \\
\hline \multirow[t]{4}{*}{ Educational background } & $\begin{array}{l}\text { Senior (vocational) high } \\
\text { school or below }\end{array}$ & 146 & 42.7 \\
\hline & Junior college & 68 & 19.9 \\
\hline & University & 114 & 33.3 \\
\hline & Graduate institute or above & 14 & 4.1 \\
\hline \multirow[t]{5}{*}{ Monthly income } & Less than NTD 20,000 & 21 & 6.1 \\
\hline & NTD 20,001-30,000 & 184 & 53.8 \\
\hline & NTD 30,001-40,000 & 82 & 24.0 \\
\hline & NTD 40,001-50,000 & 34 & 9.9 \\
\hline & Over NTD 50,001 & 21 & 6.1 \\
\hline \multirow{6}{*}{$\begin{array}{l}\text { Department of } \\
\text { employment }\end{array}$} & Housekeeping & 92 & 26.9 \\
\hline & Food and beverage & 157 & 45.9 \\
\hline & Maintenance & 23 & 6.7 \\
\hline & Sales and marketing & 12 & 3.5 \\
\hline & Accounting & 48 & 14.0 \\
\hline & Other & 10 & 3.0 \\
\hline \multirow[t]{2}{*}{ Position } & Supervisor & 57 & 16.7 \\
\hline & Non-supervisor & 285 & 83.3 \\
\hline \multirow[t]{4}{*}{ Years of service } & Under 3 years & 136 & 39.8 \\
\hline & $4-5$ years & 67 & 19.6 \\
\hline & 6-10 years & 56 & 16.4 \\
\hline & 11-15 years & 33 & 9.6 \\
\hline
\end{tabular}


The Effects of Training and Reward Systems on Employee Willingness to Stay - A Case Study of an International Tourist Hotel in Taipei

\begin{tabular}{|c|l|c|c|}
\hline \hline \multirow{2}{*}{ Child status } & $16-20$ years & 24 & 7.0 \\
\cline { 2 - 4 } & Over 21 years & 26 & 7.6 \\
\hline \multirow{3}{*}{} & Have child(ren) & 147 & 43.0 \\
\cline { 2 - 4 } & Childless & 195 & 57.0 \\
\hline
\end{tabular}

Note: Valid \% totals not equaling $100.0 \%$ were caused by rounding

\subsection{Differences in Constructs with Regard to Various Demographic Variables}

\subsubsection{T test of gender and constructs}

A $t$ test revealed significant gender differences in results regarding training effectiveness and income and promotion opportunities, which are sub-question items of training effectiveness. Male employees gave higher scores than female employees on average, which means that they attach more importance to salaries and promotions. Significant gender differences also existed in that men demonstrated higher willingness to stay. The remaining constructs showed no significant differences with regard to gender, as shown in Table 2.

Table2. Results of $t$ test of gender and constructs

\begin{tabular}{|c|c|c|c|c|c|}
\hline Variable & Construct & Gender & $M$ & $S D$ & $F$ value \\
\hline \multirow{4}{*}{$\begin{array}{l}\text { Training } \\
\text { system }\end{array}$} & \multirow[t]{2}{*}{ Training motive } & Male & 3.82 & .609 & \multirow[t]{2}{*}{$-.104 * *$} \\
\hline & & Female & 3.70 & .541 & \\
\hline & \multirow[t]{2}{*}{ Training effectiveness } & Male & 3.69 & .692 & \multirow[t]{2}{*}{$.716 * *$} \\
\hline & & Female & 3.43 & .546 & \\
\hline \multirow{6}{*}{$\begin{array}{l}\text { Reward } \\
\text { system }\end{array}$} & \multirow[t]{2}{*}{ Extrinsic financial rewards } & Male & 3.37 & .575 & \multirow[t]{2}{*}{$.057 * *$} \\
\hline & & Female & 3.29 & .611 & \\
\hline & \multirow{2}{*}{$\begin{array}{l}\text { Extrinsic non-financial } \\
\text { rewards }\end{array}$} & Male & 3.50 & .596 & \multirow[t]{2}{*}{$.597 * *$} \\
\hline & & Female & 3.33 & .576 & \\
\hline & \multirow[t]{2}{*}{ Intrinsic rewards } & Male & 3.55 & .628 & \multirow[t]{2}{*}{$3.599 * *$} \\
\hline & & Female & 3.43 & .567 & \\
\hline \multirow{4}{*}{$\begin{array}{l}\text { Willingness } \\
\text { to stay }\end{array}$} & \multirow{2}{*}{$\begin{array}{l}\text { Willingness to stay in the } \\
\text { organization }\end{array}$} & Male & 3.76 & .627 & \multirow[t]{2}{*}{$4.183 * *$} \\
\hline & & Female & 3.40 & .567 & \\
\hline & \multirow{2}{*}{$\begin{array}{l}\text { Willingness to stay in the } \\
\text { profession }\end{array}$} & Male & 3.34 & .470 & \multirow[t]{2}{*}{$2.546 * *$} \\
\hline & & Female & 3.21 & .451 & \\
\hline
\end{tabular}

$* p<.05 * * p<.01 * * * p<.001$

\subsubsection{T Test of Marital Status and Constructs}

The results indicate that marital status had no significant influence on feelings regarding training systems and reward systems but made a significant difference in willingness to stay. It is possible that single employees are more likely to generate turnover intentions when their colleagues quit or when they suffer from work-related stress or overly long working hours. In contrast, married employees are more willing to stay, perhaps for the sake of their families, as shown in Fig. 3.

Table3. Results of t test of marital status and constructs

\begin{tabular}{|c|c|c|c|c|c|}
\hline Variable & Construct & Marital Status & $M$ & $S D$ & $F$ value \\
\hline \multirow{4}{*}{$\begin{array}{l}\text { Training } \\
\text { system }\end{array}$} & \multirow[t]{2}{*}{ Training motive } & Single & 3.74 & .633 & \multirow[t]{2}{*}{$1.889 * * * *$} \\
\hline & & Married & 3.76 & .497 & \\
\hline & \multirow[t]{2}{*}{ Training effectiveness } & Single & 3.48 & .653 & \multirow[t]{2}{*}{$1.111 * *$} \\
\hline & & Married & 3.59 & .582 & \\
\hline \multirow{6}{*}{$\begin{array}{l}\text { Reward } \\
\text { system }\end{array}$} & \multirow[t]{2}{*}{ Extrinsic financial rewards } & Single & 3.37 & .576 & \multirow[t]{2}{*}{$1.091 * *$} \\
\hline & & Married & 3.27 & .617 & \\
\hline & \multirow[t]{2}{*}{ Extrinsic non-financial rewards } & Single & 3.38 & .616 & \multirow[t]{2}{*}{$.505 * *$} \\
\hline & & Married & 3.42 & .562 & \\
\hline & \multirow[t]{2}{*}{ Intrinsic rewards } & Single & 3.50 & .588 & \multirow[t]{2}{*}{$.326 * *$} \\
\hline & & Married & 3.46 & .605 & \\
\hline \multirow{4}{*}{$\begin{array}{l}\text { Willingness } \\
\text { to stay }\end{array}$} & \multirow{2}{*}{$\begin{array}{l}\text { Willingness to stay in the } \\
\text { organization }\end{array}$} & Single & 3.33 & .834 & \multirow[t]{2}{*}{$5.483 * *$} \\
\hline & & Married & 3.79 & .705 & \\
\hline & \multirow{2}{*}{$\begin{array}{l}\text { Willingness to stay in the } \\
\text { profession }\end{array}$} & Single & 3.28 & .485 & \multirow[t]{2}{*}{$.615 * *$} \\
\hline & & Married & 3.25 & .438 & \\
\hline
\end{tabular}

$* p<.05 * * p<.01 * * * p<.001$ 


\subsubsection{Differences in Constructs with Regard to Age}

A one-way ANOVA indicated that age was not correlated with any significant differences in perceptions of the training system. When questioned about their feelings regarding reward systems, significant differences were only found regarding feelings on extrinsic non-financial rewards. A post-hoc analysis using Scheffe's method revealed that employees over 51 years of age possessed more cognition than those between 18 and 30 years of age. This is possibly because employees over 51 years of age have had fewer learning and training opportunities outside the company. In the willingness to stay construct, only willingness to stay in the organization presented significant differences. Moreover, a post-hoc analysis using Scheffe's method revealed that employees over 51 years of age possessed more cognition than those between 31 and 40 years of age and those between 18 and 30 years of age, while employees between 41 and 50 years of age possessed more cognition than those between 18 and 30 years of age, as shown in Table 4 .

Table4. Age and Relationship to Various Constructs

\begin{tabular}{|c|c|c|c|c|}
\hline Age & Variable & Construct & $F$ value & Scheffe \\
\hline \multirow{7}{*}{$\begin{array}{l}\text { 1. } 18-30 \text { years old } \\
\text { 2. } 31-40 \text { years old } \\
\text { 3. } 41-50 \text { years old } \\
\text { 4. over } 51 \text { years old }\end{array}$} & \multirow[t]{2}{*}{ Training system } & Training motive & $.550 * *$ & - \\
\hline & & Training effectiveness & $2.279 * *$ & - \\
\hline & \multirow[t]{3}{*}{ Reward system } & Extrinsic financial rewards & $.342 * *$ & - \\
\hline & & Extrinsic non-financial rewards & $2.698 * *$ & $4>1$ \\
\hline & & Intrinsic rewards & $1.587 * *$ & - \\
\hline & \multirow[t]{2}{*}{ Willingness to stay } & $\begin{array}{l}\text { Willingness to stay in the } \\
\text { organization }\end{array}$ & $19.320 * *$ & $4>2,4>1,3>1$ \\
\hline & & Willingness to stay in the profession & $2.369 * *$ & - \\
\hline
\end{tabular}

$*_{p}<.05 * * p<.01 * * * p<.001$

\subsubsection{Differences in Constructs with Regard to Educational Background}

Educational background was only coordinated with the training effectiveness in the training system construct. A post-hoc analysis using Scheffe's method showed that employees that had attained a senior or vocational high school degree but had not gone on to further education possessed more cognition than those with a bachelor's degree. Educational background also exerted significant influence on extrinsic financial and non-financial rewards, and employees with a junior college degree possessed more cognition than those with a bachelor's degree or a senior or vocational high school degree. Educational background had a significant impact on willingness to stay in the organization. A post-hoc analysis using Scheffe's method showed that employees with a junior college degree or a senior or vocational high school degree possessed more cognition than those with a bachelor's degree, as shown in Table 5.

Table5. Educational Background and Relationship to Various Constructs

\begin{tabular}{|l|l|l|r|r|}
\hline \multicolumn{1}{|c|}{$\begin{array}{l}\text { Educational } \\
\text { background }\end{array}$} & \multicolumn{1}{|c|}{ Variable } & \multicolumn{1}{|c|}{ Construct } & Scheffe \\
\hline $\begin{array}{l}\text { 1. Senior } \\
\text { (vocational) high } \\
\text { school or below }\end{array}$ & Training system & Training motive & $.394^{* *}$ & - \\
\cline { 2 - 5 } $\begin{array}{l}\text { 2. Junior college } \\
\text { 3. University }\end{array}$ & Reward system & Training effectiveness & $4.554^{* *}$ & $1>3$ \\
\cline { 2 - 5 } $\begin{array}{l}\text { 4. Graduate } \\
\text { institute or above }\end{array}$ & Willingness to & Extrinsic non-financial rewards & $3.140^{* *}$ & $2>3,2>1$ \\
\cline { 2 - 5 } & Stay & Intrinsic rewards & $.711^{* *}$ & $2>1>3$ \\
\cline { 2 - 5 } & Willingness to stay in the organization & $14.661^{* *}$ & $1>3,2>3$ \\
\hline
\end{tabular}

$*_{p}<.05 * * p<.01 * * * p<.001$

\subsubsection{Monthly Income and Relationship to Various Constructs}

Among the various constructs, monthly income only exerted significant influence on intrinsic rewards and willingness to stay in the organization, as shown in Table 6.

Table6. Monthly Income and its Relationship to Various Constructs

\begin{tabular}{|c|c|c|c|c|}
\hline Monthly income & Variable & Construct & $F$ value & Scheffe \\
\hline 1. Less than NTD & Training system & Training motive & $1.371 * *$ & - \\
\hline 20,000 & & Training effectiveness & $1.176 * *$ & - \\
\hline
\end{tabular}


The Effects of Training and Reward Systems on Employee Willingness to Stay - A Case Study of an International Tourist Hotel in Taipei

\begin{tabular}{|l|l|l|r|r|}
\hline \hline 2. NTD 20,001-30,000 & Reward system & Extrinsic financial rewards & $2.021^{* *}$ & \\
\cline { 3 - 5 } $\begin{array}{l}\text { 3. NTD 30,001-40,000 } \\
\text { 4. NTD 40,001-50,000 }\end{array}$ & & Extrinsic non-financial rewards & $.851^{* *}$ & - \\
\cline { 3 - 5 } 5. Over NTD 50,001 & Intrinsic rewards & $2.526^{* *}$ & - \\
\cline { 3 - 5 } & Willingness to stay & $\begin{array}{l}\text { Willingness to stay in the } \\
\text { organization }\end{array}$ & $2.436^{* *}$ & - \\
\cline { 3 - 5 } & & Willingness to stay in the profession & $1.413^{* *}$ & - \\
\hline
\end{tabular}

$* p<.05 * * p<.01 * * * p<.001$

\subsubsection{Department of Employment}

The department of employment exerted significant influence on training effectiveness. A post-hoc analysis using Scheffe's method showed that employees working in the housekeeping department possessed more cognition than those in the maintenance and accounting departments. In willingness to stay, significant differences were found in both willingness to stay in the organization and willingness to stay in the profession. Also, a post-hoc analysis using Scheffe's method showed that employees working in the housekeeping department possessed more cognition than those in the food and beverage department, as shown in Table 7.

Table7. Department of Employment and Relationship to Various Constructs

\begin{tabular}{|l|l|l|l|l|}
\hline Department & Variable & Construct & $F$ value & Scheffe \\
\hline $\begin{array}{l}\text { 1. Housekeeping } \\
\text { 2. Food and beverage }\end{array}$ & Training system & Training motive & $1.092^{* *}$ & - \\
\cline { 2 - 5 } $\begin{array}{l}\text { 3. Maintenance } \\
\text { 4. Sales and marketing }\end{array}$ & & Training effectiveness & $4.913^{* *}$ & $1>3,1>5$ \\
\cline { 2 - 5 } $\begin{array}{l}\text { 5. Accounting } \\
\text { 6. Other }\end{array}$ & Reward system & Extrinsic financial rewards & $.853^{* *}$ & - \\
\cline { 3 - 5 } & Extrinsic non-financial rewards & $.847^{* *}$ & - \\
\cline { 2 - 5 } & \multirow{2}{*}{$\begin{array}{l}\text { Willingness to } \\
\text { stay }\end{array}$} & $\begin{array}{l}\text { Intrinsic rewards } \\
\text { Oillingness to stay in the }\end{array}$ & $3.065^{* *}$ & - \\
\cline { 2 - 5 } & & Willingness to stay in the profession & $3.358^{* *}$ & - \\
\hline
\end{tabular}

$* p<.05 * * p<.01 * * * p<.001$

\subsubsection{T test for position and constructs}

A $t$ test for position and the various constructs indicated no significant differences, as shown in Table 8 .

Table8. Results of t test of position and constructs

\begin{tabular}{|c|c|c|c|c|c|}
\hline Variable & Construct & Position & $M$ & $S D$ & $F$ value \\
\hline \multirow{4}{*}{$\begin{array}{l}\text { Training } \\
\text { system }\end{array}$} & \multirow{2}{*}{ Training motive } & Supervisor & 3.79 & .508 & \multirow[t]{2}{*}{$.326^{* *}$} \\
\hline & & Non-supervisor & 3.75 & .548 & \\
\hline & \multirow[t]{2}{*}{ Training effectiveness } & Supervisor & 3.65 & .596 & \multirow[t]{2}{*}{$.498 * *$} \\
\hline & & Non-supervisor & 3.51 & .626 & \\
\hline \multirow{6}{*}{$\begin{array}{l}\text { Reward } \\
\text { system }\end{array}$} & \multirow{2}{*}{$\begin{array}{l}\text { Extrinsic financial } \\
\text { rewards }\end{array}$} & Supervisor & 3.51 & .509 & \multirow[t]{2}{*}{$1.897 * *$} \\
\hline & & Non-supervisor & 3.29 & .607 & \\
\hline & \multirow{2}{*}{$\begin{array}{l}\text { Extrinsic non-financial } \\
\text { rewards }\end{array}$} & Supervisor & 3.54 & .493 & \multirow[t]{2}{*}{$2.890 * *$} \\
\hline & & Non-supervisor & 3.37 & .605 & \\
\hline & \multirow[t]{2}{*}{ Intrinsic rewards } & Supervisor & 3.65 & .500 & \multirow[t]{2}{*}{$3.570 * *$} \\
\hline & & Non-supervisor & 3.45 & .608 & \\
\hline \multirow{4}{*}{$\begin{array}{l}\text { Willingness } \\
\text { to stay }\end{array}$} & \multirow{2}{*}{$\begin{array}{l}\text { Willingness to stay in the } \\
\text { organization }\end{array}$} & Supervisor & 3.71 & .706 & \multirow[t]{2}{*}{$* 1.992 * *$} \\
\hline & & Non-supervisor & 3.51 & .824 & \\
\hline & \multirow{2}{*}{$\begin{array}{l}\text { Willingness to stay in the } \\
\text { profession }\end{array}$} & Supervisor & 3.27 & .448 & \multirow[t]{2}{*}{$.114 * *$} \\
\hline & & Non-supervisor & 3.26 & .467 & \\
\hline
\end{tabular}

$*_{p}<.05 * * p<.01 * * * p<.001$

\subsubsection{Years of Service}

As shown in Table 9, years of service exerted significant influence on willingness to stay in the organization and willingness to stay in the profession. A post-hoc analysis using Scheffe's method showed that senior employees were more willing to stay. This is possibly because they have higher positions and salaries after years of service. 
Ya-Hsin Cheng \& Hung-Sheng Herman Lai

Table9. Years of Service and Relationship to Various Constructs

\begin{tabular}{|c|c|c|c|c|}
\hline Years of service & Variable & Construct & $F$ value & Scheffe \\
\hline \multirow{7}{*}{$\begin{array}{l}\text { 1. Under } 3 \text { years } \\
\text { 2. } 4-5 \text { years } \\
\text { 3. 6-10 years } \\
\text { 4. } 11-15 \text { years } \\
\text { 5. 16-20 years } \\
\text { 6. Over } 21 \text { years }\end{array}$} & \multirow[t]{2}{*}{ Training system } & Training motive & $.817 * *$ & - \\
\hline & & Training effectiveness & $1.194 * *$ & - \\
\hline & \multirow[t]{3}{*}{ Reward system } & $\begin{array}{ll}\text { Extrinsic } & \text { financial } \\
\text { rewards } & \\
\end{array}$ & $1.596 * *$ & - \\
\hline & & $\begin{array}{l}\text { Extrinsic non-financial } \\
\text { rewards }\end{array}$ & $1.839 * *$ & - \\
\hline & & Intrinsic rewards & $2.127 * *$ & - \\
\hline & \multirow[t]{2}{*}{ Willingness to stay } & $\begin{array}{l}\text { Willingness to stay in } \\
\text { the organization }\end{array}$ & $7.061 * *$ & $6>1,4>1,4>2$ \\
\hline & & $\begin{array}{l}\text { Willingness to stay in } \\
\text { the profession }\end{array}$ & $6.168 * *$ & $3>2,4>2,5>2,5>6$ \\
\hline
\end{tabular}

$* p<.05 * * p<.01 * * * p<.001$

\subsubsection{T Test of Child Status and Constructs}

Among the various constructs, child status only had a significant impact on willingness to stay in the organization, as shown in Table 10.

Table10. Results of t test of child status and constructs

\begin{tabular}{|c|c|c|c|c|c|}
\hline Variable & Construct & Child status & $M$ & $S D$ & $F$ value \\
\hline \multirow{4}{*}{$\begin{array}{l}\text { Training } \\
\text { system }\end{array}$} & \multirow[t]{2}{*}{ Training motive } & Have child(ren) & 3.75 & .495 & \multirow[t]{2}{*}{$1.590 * *$} \\
\hline & & Childless & 3.75 & .625 & \\
\hline & \multirow[t]{2}{*}{ Training effectiveness } & Have child(ren) & 3.63 & .570 & \multirow[t]{2}{*}{$1.385 * *$} \\
\hline & & Childless & 3.47 & .652 & \\
\hline \multirow{6}{*}{$\begin{array}{l}\text { Reward } \\
\text { system }\end{array}$} & \multirow{2}{*}{$\begin{array}{ll}\text { Extrinsic } & \text { financial } \\
\text { rewards } & \\
\end{array}$} & Have child(ren) & 3.30 & .610 & \multirow[t]{2}{*}{$.565 * *$} \\
\hline & & Childless & 3.34 & .588 & \\
\hline & \multirow{2}{*}{$\begin{array}{l}\text { Extrinsic non-financial } \\
\text { rewards }\end{array}$} & Have child(ren) & 3.44 & .550 & \multirow[t]{2}{*}{$.602 * *$} \\
\hline & & Childless & 3.37 & .619 & \\
\hline & \multirow[t]{2}{*}{ Intrinsic rewards } & Have child(ren) & 3.49 & .610 & \multirow[t]{2}{*}{$* .508 * *$} \\
\hline & & Childless & 3.48 & .585 & \\
\hline \multirow{4}{*}{$\begin{array}{l}\text { Willingness } \\
\text { to stay }\end{array}$} & \multirow{2}{*}{$\begin{array}{l}\text { Willingness to stay in the } \\
\text { organization }\end{array}$} & Have child(ren) & 3.85 & .671 & \multirow[t]{2}{*}{$8.843 * *$} \\
\hline & & Childless & 3.33 & .830 & \\
\hline & \multirow{2}{*}{$\begin{array}{l}\text { Willingness to stay in the } \\
\text { profession }\end{array}$} & Have child(ren) & 3.28 & .463 & \multirow[t]{2}{*}{$.211 * *$} \\
\hline & & Childless & 3.25 & .464 & \\
\hline
\end{tabular}

$* p<.05 * * p<.01 * * * p<.001$

\subsection{Pearson Correlation Analysis}

\subsubsection{Correlation Analysis of Educational Training and Willingness to Stay}

As shown in Table 11, the items in the training system were only weakly correlated with the items regarding willingness to stay and were negatively correlated to "A coworker quitting makes me also want to quit" and "Work-related stress, overly long work hours, and salary issues are the main reasons that make me want to quit."

Table11. Pearson coefficients for training motive and willingness to stay

\begin{tabular}{|l|l|l|l|l|l|l|l|l|l|}
\hline & $\begin{array}{l}\text { Will } \\
\text { continue to } \\
\text { stay }\end{array}$ & $\begin{array}{l}\text { Will keep } \\
\text { staying }\end{array}$ & $\begin{array}{l}\text { No } \\
\text { better fit }\end{array}$ & $\begin{array}{l}\text { Never } \\
\text { hunted } \\
\text { for other } \\
\text { jobs }\end{array}$ & $\begin{array}{l}\text { Not } \\
\text { changing } \\
\text { industries }\end{array}$ & $\begin{array}{l}\text { Focus of } \\
\text { career } \\
\text { development }\end{array}$ & $\begin{array}{l}\text { Never } \\
\text { thought of } \\
\text { transferring }\end{array}$ & $\begin{array}{l}\text { Turnover } \\
\text { intention }\end{array}$ & $\begin{array}{l}\text { Work-related } \\
\text { stress }\end{array}$ \\
\hline $\begin{array}{l}\text { Salary and } \\
\text { income }\end{array}$ & $.163(* *)$ & $.171(* *)$ & $.184(* *)$ & 0.065 & $.194(* *)$ & $.219(* *)$ & $.182(* *)$ & -0.016 & 0.032 \\
\hline $\begin{array}{l}\text { Promotion } \\
\text { opportunities }\end{array}$ & $.148(* *)$ & $.126(*)$ & 0.079 & 0.064 & $.120(*)$ & $.186(* *)$ & 0.096 & -0.029 & -0.007 \\
\hline $\begin{array}{l}\text { Work } \\
\text { efficiency }\end{array}$ & $.144(* *)$ & 0.059 & 0.028 & 0.066 & 0.041 & 0.09 & 0.088 & -0.078 & 0.031 \\
\hline $\begin{array}{l}\text { Professional } \\
\text { knowledge } \\
\text { and }\end{array}$ & $.168(* *)$ & 0.074 & 0.015 & 0.069 & -0.013 & 0.066 & 0.051 & $-.154(* *)$ & 0.031 \\
\hline
\end{tabular}


The Effects of Training and Reward Systems on Employee Willingness to Stay - A Case Study of an International Tourist Hotel in Taipei

\begin{tabular}{|l|l|l|l|l|l|l|l|l|l|}
\hline skills & & & & & & & & \\
\hline $\begin{array}{l}\text { Interpersonal } \\
\text { relationships }\end{array}$ & $.178(* *)$ & $.191(* *)$ & $.153(* *)$ & $.212^{(* *)}$ & 0.101 & $.206(* *)$ & $.187(* *)$ & -0.084 & -0.046 \\
\hline $\begin{array}{l}\text { Career } \\
\text { development } \\
\text { plans }\end{array}$ & $.174(* *)$ & $.133(*)$ & $.143(* *)$ & $\left..120^{*}\right)$ & $\left..119^{*}\right)$ & $.196(* *)$ & $.153(* *)$ & $-.165(* *)$ & -0.078 \\
\hline
\end{tabular}

$N=342$

As shown in Table 12, the items regarding training effectiveness showed significant correlations with the items regarding willingness to stay and were negatively correlated to "A coworker quitting makes me also want to quit" and "Work-related stress, overly long work hours, and salary issues are the main reasons that make me want to quit."

Table12. Pearson Coefficients for Training Effectiveness and Willingness to Stay

\begin{tabular}{|c|c|c|c|c|c|c|c|c|c|}
\hline & $\begin{array}{l}\text { Will } \\
\text { continue } \\
\text { to stay } \\
\end{array}$ & $\begin{array}{l}\text { Will } \\
\text { keep } \\
\text { staying }\end{array}$ & $\begin{array}{l}\text { No } \\
\text { better } \\
\text { fit }\end{array}$ & $\begin{array}{l}\text { Never } \\
\text { hunted for } \\
\text { other jobs }\end{array}$ & $\begin{array}{l}\text { Not } \\
\text { changing } \\
\text { industries } \\
\end{array}$ & $\begin{array}{l}\text { Focus of } \\
\text { career } \\
\text { development }\end{array}$ & $\begin{array}{l}\text { Never } \\
\text { thought of } \\
\text { transferring }\end{array}$ & $\begin{array}{l}\text { Turnover } \\
\text { intention }\end{array}$ & $\begin{array}{l}\text { Work-related } \\
\text { stress }\end{array}$ \\
\hline $\begin{array}{l}\text { Suitable work } \\
\text { time }\end{array}$ & $.337(* *)$ & $.344(* *)$ & $.329(* *)$ & $.327(* *)$ & $.306(* *)$ & $.293(* *)$ & $.391(* *)$ & $-208(* * *)$ & $-.193(* *)$ \\
\hline \begin{tabular}{l|} 
Suitable \\
number of \\
work hours
\end{tabular} & $.376(* *)$ & $.372(* *)$ & $.375(* *)$ & $314(* * *)$ & $.333(* *)$ & $.344(* *)$ & $.414(* *)$ & $-.206(* *)$ & $-.220(* *)$ \\
\hline Rich content & $.304(* *)$ & $.374(* *)$ & $.398(* *)$ & $.313(* *)$ & $.304(* *)$ & $.352(* *)$ & $.437(* * *)$ & -.222 (**) & -.249 (**) \\
\hline $\begin{array}{l}\text { Satisfactory } \\
\text { workplace } \\
\text { equipment }\end{array}$ & $.370^{(* * *)}$ & $.367(* *)$ & $.385(* *)$ & $.352(* *)$ & $.339(* *)$ & $.397(* * *)$ & $.387(* * *)$ & -180 (**) & $-.233(* *)$ \\
\hline $\begin{array}{l}\text { Satisfactory } \\
\text { teaching } \\
\text { materials } \\
\end{array}$ & $.343(* *)$ & $.342(* *)$ & $.358(* *)$ & $.318(* *)$ & $.287(* *)$ & $.352(* *)$ & $.344(* *)$ & $-.197(* *)$ & $-.217(* *)$ \\
\hline $\begin{array}{l}\text { Satisfactory } \\
\text { teaching } \\
\text { methods } \\
\end{array}$ & $.397(* *)$ & $.389(* *)$ & .412 (**) & $.384(* *)$ & $.347(* * *)$ & $.392(* *)$ & $.420(* *)$ & $-.204(* *)$ & $-.272(* *)$ \\
\hline $\begin{array}{l}\text { Meets } \\
\text { learning } \\
\text { needs } \\
\end{array}$ & $.324(* *)$ & $.399(* * *)$ & $.401(* *)$ & $.366(* *)$ & $.370(* *)$ & $.330(* *)$ & $373(* *)$ & $-.296(* *)$ & $-.259(* *)$ \\
\hline $\begin{array}{l}\text { Helpful to } \\
\text { learning and } \\
\text { development }\end{array}$ & $.333(* *)$ & $.291(* *)$ & $.340(* *)$ & $.293(* *)$ & $.263(* *)$ & .259 (***) & $.304(* *)$ & $-277(* *)$ & $-.235(* *)$ \\
\hline $\begin{array}{l}\text { Enhances } \\
\text { skills }\end{array}$ & $.313(* *)$ & $.337(* *)$ & $.354(* *)$ & $.281(* *)$ & $.274(* *)$ & $.352(* *)$ & $335(* *)$ & $-.262(* *)$ & $-.218(* *)$ \\
\hline $\begin{array}{l}\text { Quickly } \\
\text { completes } \\
\text { work tasks } \\
\end{array}$ & $.297(* * *)$ & $.279(* *)$ & $.319(* *)$ & $.330(* *)$ & $.280(* * *)$ & $.367(* *)$ & $.300(* *)$ & $-.155(* *)$ & $-.153(* *)$ \\
\hline $\begin{array}{l}\text { Work } \\
\text { confidence }\end{array}$ & $.340(* *)$ & $.356(* *)$ & $.391(* *)$ & $.404(* *)$ & $.326(* *)$ & $.393(* *)$ & $.384(* *)$ & $-.221(* *)$ & -.209 (**) \\
\hline $\begin{array}{l}\text { Service } \\
\text { quality }\end{array}$ & $.362^{(* *)}$ & $.336(* *)$ & $.361(* *)$ & $.282(* *)$ & $.268(* *)$ & $.337(* * *)$ & $314(* *)$ & $-.266(* * *)$ & $-.216(* *)$ \\
\hline
\end{tabular}

$N=342$

As can be seen in Table 13, significant, moderate, and positive correlation exists between the constructs training system and willingness to stay, which means that if employees are more satisfied with the training system, they will be more willing to stay. Satisfactory training effectiveness had the most significant impact.

Table13. Overall Pearson correlation coefficient of training system and willingness to stay

\begin{tabular}{|l|c|r|}
\hline \multicolumn{2}{|c|}{} & \multicolumn{1}{|c|}{ Willingness to stay } \\
\hline \multirow{2}{*}{ Training system } & Pearson correlation & $.452(* *)$ \\
\cline { 2 - 3 } & Significance (two-tailed) & .000 \\
\hline
\end{tabular}

$N=342$ 


\subsubsection{Correlation Analysis for Reward System and Willingness to Stay}

As shown in Table 14, the items regarding training system showed significant but moderate correlation with the items regarding willingness to stay and were negatively correlated to "A coworker quitting makes me also want to quit" and "Work pressure, overly long work hours, and salary issues are the main reasons that make me want to quit."

Table14. Pearson coefficients for reward system and willingness to stay

\begin{tabular}{|c|c|c|c|c|c|c|c|c|c|}
\hline & $\begin{array}{l}\text { Will } \\
\text { continue } \\
\text { to stay }\end{array}$ & $\begin{array}{l}\text { Will } \\
\text { keep } \\
\text { staying }\end{array}$ & $\begin{array}{l}\text { No } \\
\text { better } \\
\text { fit }\end{array}$ & $\begin{array}{l}\text { Never } \\
\text { hunted for } \\
\text { other jobs }\end{array}$ & $\begin{array}{l}\text { Not } \\
\text { changing } \\
\text { industries } \\
\end{array}$ & \begin{tabular}{|l} 
Focus of \\
career \\
development
\end{tabular} & \begin{tabular}{|l|} 
Never \\
thought of \\
transferring
\end{tabular} & $\begin{array}{l}\text { Turnover } \\
\text { intention }\end{array}$ & $\begin{array}{l}\text { Work-relate } \\
\text { d stress }\end{array}$ \\
\hline Salary & .317 (**) $^{* *}$ & $.327(* *)$ & $.344(* *)$ & .353 (**) $^{* *}$ & $330^{(* *)}$ & $.343(* *)$ & $312(* *)$ & -0.066 & $-.196(* *)$ \\
\hline $\begin{array}{l}\text { Dividends } \\
\text { allotment }\end{array}$ & $.205(* *)$ & $.274(* *)$ & $.290(* *)$ & $.291(* *)$ & .307 (**) & $.338(* *)$ & $.330(* *)$ & -0.061 & $-.114(*)$ \\
\hline $\begin{array}{l}\text { Three Chinese } \\
\text { festival } \\
\text { bonuses }\end{array}$ & $.212(* *)$ & $.128(*)$ & $.163(* *)$ & $.287(* *)$ & $.168(* *)$ & $.275(* *)$ & $.205(* *)$ & 0.038 & -0.101 \\
\hline $\begin{array}{l}\text { Year-end } \\
\text { bonuses }\end{array}$ & $.338(* *)$ & $.294(* *)$ & $.282(* *)$ & .319 (**) & $.285(* *)$ & $.389(* *)$ & .339 (**) & $-.154(* *)$ & $-.198(* *)$ \\
\hline Stable work & .425 (**) & $.442(* *)$ & .336 (**) & .299 (**) & 315 (**) & $.314(* *)$ & $.371(* *)$ & $-.125(*)$ & -.153 (**) \\
\hline $\begin{array}{l}\text { Promotion } \\
\text { opportunities }\end{array}$ & $.304(* *)$ & .359 (**) & $.347(* *)$ & .351 (**) & .349 (**) & $.353(* *)$ & $.354(* *)$ & $-.152(* *)$ & $-.197(* * *)$ \\
\hline $\begin{array}{l}\text { On-the-job } \\
\text { training }\end{array}$ & $.378(* *)$ & $.379(* *)$ & $.350(* *)$ & $.359(* *)$ & $.300(* *)$ & $.333(* *)$ & $.369(* *)$ & $-.222(* *)$ & $-.206(* *)$ \\
\hline $\begin{array}{l}\text { Fair } \\
\text { assessments }\end{array}$ & $.284(* *)$ & $.289(* *)$ & $.264(* *)$ & $.384(* *)$ & $.260^{(* *)}$ & $.317(* *)$ & $342^{(* * *)}$ & $-.110(*)$ & $-.201(* *)$ \\
\hline $\begin{array}{l}\text { Rich work } \\
\text { content }\end{array}$ & $.402(* *)$ & $.365(* *)$ & $.322(* *)$ & .409 (**) & $.280(* *)$ & $.319(* *)$ & $369(* *)$ & $-.144(* *)$ & $-.183(* *)$ \\
\hline Complete work & $.388(* *)$ & $.319(* *)$ & $.338(* *)$ & $.365(* *)$ & $.276(* *)$ & $.299(* *)$ & $.311(* *)$ & $-.137(*)$ & $-.192(* *)$ \\
\hline $\begin{array}{l}\text { Participation in } \\
\text { decision } \\
\text { making }\end{array}$ & $.340^{(* *)}$ & $.290(* *)$ & $.350(* *)$ & $.364(* *)$ & $.325(* *)$ & $.359(* *)$ & $.392^{(* *)}$ & $-.151(* *)$ & $-.168(* *)$ \\
\hline $\begin{array}{l}\text { Influence on } \\
\text { operations }\end{array}$ & $.434(* *)$ & $.367(* * *)$ & $.326(* *)$ & $.351(* *)$ & $.327(* * *)$ & $.417(* *)$ & $.389(* *)$ & $-.192(* *)$ & $-.155(* *)$ \\
\hline Full authority & $.409^{(* *)}$ & 319 (**) & $.307(* *)$ & $.369(* *)$ & $.335(* *)$ & $.298(* *)$ & .380 (**) & -.189 (**) & $-.221(* *)$ \\
\hline $\begin{array}{l}\text { Sense of } \\
\text { achievement }\end{array}$ & $.366(* *)$ & $.309(* *)$ & $.320(* *)$ & $.331(* *)$ & $.229(* *)$ & $.264(* *)$ & $.324(* * *)$ & $-.142(* *)$ & -0.096 \\
\hline $\begin{array}{l}\text { Public } \\
\text { commendation }\end{array}$ & $.385(* *)$ & $.318(* *)$ & $316(* *)$ & $.365(* *)$ & $.258(* *)$ & $.254(* * *)$ & $.309(* *)$ & -0.087 & $-.145(* *)$ \\
\hline
\end{tabular}

\section{$N=342$}

Table 15 shows significant and moderate correlation exists between the constructs reward system and willingness to stay, and the correlation is almost positive and high. We therefore infer that if employees are more satisfied with the reward system, they will be more willing to stay. Furthermore, the correlation between reward system and willingness to stay is greater than that between training system and willingness to stay.

Table15. Overall Pearson Correlation Coefficient for Reward System and Willingness to Stay

\begin{tabular}{|c|c|c|}
\hline $\begin{array}{c}\text { Reward } \\
\text { system }\end{array}$ & & Willingness to stay \\
\hline \multirow{2}{*}{$\begin{array}{l}\text { Reward } \\
\text { system }\end{array}$} & Pearson correlation & $.539(* *)$ \\
\hline & Significance (two-tailed) & .000 \\
\hline
\end{tabular}

\section{CONCLUSIONS AND SUgGeSTIONS}

This study examined the relationships between satisfaction with training and reward systems in international tourist hotels and employee willingness to stay by surveying employees of the hotel A in Taipei. Based on analysis of the results, we arrived at the following conclusions and formulated specific suggestions for the reference of international hotel operators.

\subsection{Conclusions}

\subsubsection{Difference in Employees with Regard to Training System Satisfaction}

The variance data of the employees with regard to the training system satisfaction indicates that employees between 18 and 30 years of age possessed greater cognition than those over 51 years of 
age, which means that younger employees attached more importance to promotion opportunities. With regard to years of service, only training motive presented a significant correlation with work efficiency, which may mean that employees that had served for a longer period of time had enhanced their work efficiency via the training system.

Male employees derived greater satisfaction from the training system than female employees, and married employees were more satisfied than single employees that the training could enhance their capabilities. Employees over 51 years of age possessed better cognition than those between 18 and 30 years of age with regard to the training provided by the company, while employees with senior or vocational high school degrees possess greater cognition than those with bachelor's degrees with regard to training effectiveness. These results indicate that older employees and those with only senior or vocational high school degrees have fewer opportunities for further study; the educational training offered by the company can therefore enhance the working capabilities and confidence of these employees. In contrast, employees with bachelor's degrees or higher generally seek opportunities for further study on their own when they lack a particular skill.

\subsubsection{Difference in Employees with Regard to Reward System}

Single employees were more satisfied with the bonuses given during the three Chinese festivals, whereas married employees were more satisfied with the on-the-job training system. Employees over 51 years of age possessed better cognition than those between 18 and 30 years of age with regard to rewards provided by the company, particularly if an individual's work had a major influence on the company's operations. This may be because the older employees generally had more experience than those between 18 and 30 years of age, the latter group comprising mainly new or less experienced employees who were less likely to be given major responsibilities. In terms of position, employees in supervisory positions possessed greater cognition, possibly because they received greater salaries, year-end bonuses, and promotion opportunities than general employees. In terms of years of service, supervisors generally gave greater authority and decision-making power to senior employees.

\subsubsection{Difference in Employees with Regard to Willingness to Stay}

Male employees were more willing to stay than female employees, which shows that male employees, often being the breadwinners of the family, are less likely to generate turnover intentions. Employees with only senior or vocational high school degrees were more willing to stay than those with junior college or university degrees. This is possibly because the former have fewer opportunities to change jobs and are qualified for fewer jobs. In contrast, employees with higher educational degrees could use their degrees to change jobs or positions more easily. Married employees displayed greater willingness to stay than single employees; if a coworker quit, the latter were more likely to generate turnover intentions. Younger employees were more susceptible to work-related stress. Furthermore, most married employees had familial responsibilities, were steadier workers, and were less likely to quit. A quitting coworker increased the turnover intention of employees that had served for less than three years. Employees that had served for 11 to 15 years possessed greater cognition than those that had served for less than 5 years. Years of service was significantly and positively correlated to willingness to stay, with turnover intentions being lower as years of service increased. Employees that had children were more willing to stay than those that did not, and overly long work hours and salary issues reduced the willingness of childless employees to stay.

\subsubsection{Correlation between Training System and Willingness to Stay}

There is a positive correlation between satisfaction with the training system and willingness to stay. Satisfaction with training effectiveness had the most significant impact. Greater cognition regarding training effectiveness in employees indicated greater willingness to stay in the organization, and greater motivation to participate in training also won the training system greater approval.

\subsubsection{Correlation between Reward System and Willingness to Stay}

This study discovered a positive correlation between satisfaction with the reward system and willingness to stay. Furthermore, the correlation between satisfaction with the reward system and willingness to stay is greater than that between satisfaction with the training system and willingness to stay. Aside from offering bonuses, the reward system should also include timely praise, open commendation, and the appropriate delegation of authority and decision-making power. This suggests that mutual trust and respect are needed among employees, as well as good channels of communication, to increase employee performance and willingness to stay. 


\subsection{Suggestions}

\subsubsection{Implementation of Reward System}

For new or less experienced employees, the implementation of a reward system means giving them adequate authority and decision-making power when they perform well. Rewards should also not be limited to money. During performance appraisals, the everyday performance of individual employees should serve as the basis for assessment, not the better performance of senior employees.

\subsubsection{Training System Plans}

Work hours are often longer in the service industry, so careful consideration should be given to training plans. We suggest that consideration must also be given to the time when training is scheduled. Trainings should not be scheduled for the non-work hours of employees because loss of personal time might cause them to have an adverse reaction to the training. Our results also revealed that younger employees and those that had served for less time possessed poorer cognition and derived less satisfaction regarding the training system than other employees. Thus, adjustments and planning is needed in this respect so that all employees might be more satisfied with training. This would then improve employee quality and organizational solidarity.

\subsubsection{Suggestions for Future Research}

This study only examined the relationships between the willingness of employees to stay and the training and reward systems used in human resource management. We suggest that future research examine how employee relationship management, the welfare system, and the salary system relate to willingness to stay. Due to time limitations and cost considerations, only one case was investigated in this study. We suggest that future studies compare the employees of international tourist hotels in different regions to expand the practical value of the results.

\section{REFERENCES}

Butterfield, K. D., Trevino, L. K., and Ball, G. A. (1996). Punishment from the manager's perspective: a grounded investigation and inductive model. Academy of Management Journal, 39, 1479-1512.

Chang,W.N.(2001), A study on the relationship between motivation and job satisfaction, Unpublished master thesis, Chang Jung Christian University, Tainan, Taiwan.

Chen, X.S. (2005). Study on the teaching of foreign language communication strategy for hotel managerial personnel, Culinary Science Journal of Yangzhou University, 22(4), 52-56.

Chung, I.C. (2007). The motivation effect of incentive schemes: an experimental study, Unpublished master thesis, National Dong Hwa University, Hualien, Taiwan.

Dessler, G. (2005). Human resource management (10th ed).Upper Saddle River:, New Jersey: Prentice Hall.

Feng, K.F. (2002). Effects of the characteristics of work force reduction and perceived justice on the employee's work attitudes, Unpublished master thesis, Chung Yuan Christian University, Taoyuan, Taiwan.

Hu, H.N. (2005). A study of training needs assessment of the wholesale travel agency, Unpublished master thesis, Shih Hsin University, Taipei, Taiwan.

Huang, C.L. (2003). Study on the appraisal of the effectiveness of employee education and training in insurance industry-case study of c company, Unpublished master thesis, Shu-Te University, Kaohsiung, Taiwan.

Huang, J.T. (2006). The study of atypical employment in international tourist hotels, Unpublished master thesis, Shih Hsin University, Taipei, Taiwan.

Lin, S.C. (2007). Relationships of core competence, training and intention to stay-a case of the hotel industry in Tainan city, Unpublished master thesis, Taiwan University of Science and Technology, Tainan, Taiwan.

Lin, S.W. (2007) Study of the effect of the policy of industry's heading west to china on the inclination to retain for oversea dispatching staff - to take c company as an example, Unpublished master thesis, National Sun Yat-sen University, Kaohsiung, Taiwan.

McLagan, P.A., and Bedrick, D. (1983). Models for excellence: the results of the ASTD training and development competency study. Training and Development Journal, 37(6), 10-20.

Robbins, S.P. (1978). Personnel: the management of human resources, Englewood Cliffs, New Jersey: Prentice Hall. 
The Effects of Training and Reward Systems on Employee Willingness to Stay - A Case Study of an International Tourist Hotel in Taipei

Saks, A.M. (2006). Antecedents and consequents of employee engagement. Journal of Managerial Psychology, 21(7), 600-619.

Schuler, R. S., and Jackson, S. E.(1987). Linking competitive strategies with human resources management practices. Academy of Management Executive, 1(3), 207-219.

Taiwan Tourism Bureau (2016). Numbers of hotels and rooms in 2016, Available at: http://admin.taiwan.net.tw/travel/statistic_h.aspx?no=300

Wang, Y.C., Chang, S.C., and Chu, C.I. (2005), Investigation of the relationship between possibilities of promotion, social support, job satisfaction and intention to stay of nurses, Tzu Chi Nursing Journal, 5(4), 90-101.

Wu, X.Z. (2004). The discussion of human resource quality improvement, Quality Journal, 40(2), 43-46.

Lee, S.Y. (2003). A Study on Motivation preference and job satisfaction of military personnel - the case of air force logistics area command, Unpublished master thesis, I-Shou University, Kaohsiung, Taiwan.

Chang, J.S. (2007). Relationships of Incentive systems, personality trait, intent-to-stay and job satisfaction, Unpublished master thesis, Da-Yeh University, Changhua,Taiwan. 